\title{
Financialization Process and the Outcomes in Developed Countries
}

\author{
Muharrem Afsar ${ }^{1}$, Asli Afsar ${ }^{1} \&$ Oytun Mecik ${ }^{2}$ \\ ${ }^{1}$ Department of Economics, Anadolu University, Eskisehir, Turkey \\ ${ }^{2}$ Department of Economics, Usak University, Usak, Turkey \\ Correspondence: Oytun Mecik, Department of Economics, Usak University, Usak, Turkey. Tel: \\ 90-276-221-2121/2343. E-mail: oytun.mecik@usak.edu.tr
}

Received: August 8, 2014

doi:10.5539/ijef.v6n12p192

\author{
Accepted: August 22, 2014 \\ Online Published: November 25, 2014 \\ URL: http://dx.doi.org/10.5539/ijef.v6n12p192
}

\begin{abstract}
After the 1980s, the neo-liberal economic policies of the Washington Consensus paradigm revealed by the market mechanism have become the dominant system. The globalization process of the world economy and the policies highlighted the concept of financialization. The balance shifted from production to finance in the financialization process and financial capital accumulation has become dominant and, local markets were opened to international capital flows. Thus the financial markets, the size of the institutions and processes have shown a significant increase in the entire world, particularly in the developed countries. This article aims to empirically explore the effects of financialization in the developed countries. For this purpose, current data were used in the paper to analyze these effects. In the paper, the process of financialization in the G8 countries was examined using data for a period of 19 years (1990-2008). The effects of financialization on GDP and employment have been analyzed by using panel data models. Findings suggest that there are important impacts of financial sector on GDP and total employment.
\end{abstract}

Keywords: financialization, financial sector, employment, GDP, developed countries

\section{Introduction}

After the 1980s, the paradigm manifested by Washington Consensus which has been formed by the coalition of USA Treasury, IMF and World Bank led to the acceptation of market mechanism as the basic mechanism of providing the scarce source assignment and sustainability of the economic growth in developing countries. Washington Consensus which is a set of reforms as a Neo-Liberal formula aims to minimize the role of government in the economy and to make the market effective in the source assignment (Sen, 2005, pp. 182-198). Thus, transition from government regimented international market system to current money regimented market system has been actualized (Hirst \& Thompson, 2007, p. 161). As the third stand of the historical process started with Neo-Liberalism, followed by globalization has been occurred as the fact of financialization (Kozanoglu, 2011, p. 14). Besides that, the changes in labor and the transformation of government have vital significance for financialization (Camacho \& Nieto, 2009, p. 253). During this process, in the whole world economy especially in USA it has been differentiations in the financial system, growth in investment and credit instruments has been accelerated surprisingly and finance sector has gained the majority in economic structure. The decrease of costs in finance sector, ability of new services presentations by the developments occurred in information and communication technologies has become effective in this. In addition, globalization provides a proportional expansion which will lead capitalism run in larger scales by expanding the previous forms of capitalism (Kumar, 2010, p. 228). Another reason why finance sector come into prominence in economy is the increasing wealth and work potential. The growth in international trade and decrease in transaction costs has grown the optimal geographical scales of enterprises in banking and finance field (Kidwell \& Peterson, 1990, p. 41).

With financialization, capital markets have advanced in extraordinary scales and it has transferred banking from based financial system to the financial system in which capital market has significant role especially in developed countries. Accordingly, firms have begun to use issuance of stocks and bond in capital market to provide funds prevalently instead of bank loans. Besides, in this process the significance of financial market, institutions and activities has increased. Concentration of competition in commodity markets and weakening in consumption propensity has decreased the profitability ratio in the real sector. Thus, decrease in premium of fixed capital investments and high profitability in short time financial investments has led real sector firms to 
start carrying also on financial sector (Ayturk, 2011, pp. 63-66).

In the study, it has given coverage to a summary about the relevant literature by examining developments occurred in financialization process and the result of this process on national economies. In the sequel, it has been used panel data models by benefiting from data of G8 countries on behalf of the most developed economies of the world where it could be observed the financialization process effectively. In this context, it is aimed to reach the results of financialization process occurred in developed economies.

\section{Financialization Process and Results}

The finance sector of economy contains financial instruments, financial institutions and financial markets. The trade of financial instruments is materialized by financial institutions. Financial sector undertakes a significant function in manipulating capital to ones demanding individual funds or ones having funding gaps (Kaufman, 1973, p. 39). Consequently, finance has a role of an instrument which provides investments to be materialized in the process of traditional capital accumulation. In this context, it can be expected that financial capital to secure the producer foundations in the economy by increasing the real capital stock (Aydin, 2007, pp. 320-322). The recent history of world economy has witnessed a period in which finance sector gained importance in economic structure. In fact, in the first five years of $2000 \mathrm{~s}$, the global finance assets increased to $316 \%$ of world annual production (Standing, 2010, p. 59). In this process, the common economic perception provided that financial markets to be perceived as a mechanism providing economic efficiency and growth. However, when current economic cycles and crises are observed, it is understood that interaction between financial sector and real sector does not occur in such success (Ercan, 2012). For as much as, crises are becoming more and more common with growth and expansion of global capital movement showing sudden increases and decreases; beyond being an unfortunate incident (United Nations, 2008, p. 506). Hence, it is obvious that the crisis which influenced world economy gradually after year of 2007 was a conventional crisis of financialized capitalism literally. Because this crisis, despite it resulted in a significant fail in process of accumulation, was not arisen from a problem of production in direct and transition of banks and other financial institutions in financialization process has become effective in the globalization of the crisis (Lapavitsas, 2009, p. 25).

In literature, it has been propounded different view regarding to financialization. In that context, financialization has ensued as concept defining the increasing importance of financial market, financial motives, financial institutions and financial privileged which take part in process of economy in national and international levels (Palley, 2007, p. 3). Financialization appears as increase of scale and significance of financial markets and financial institutions in modern economies. Within this scope, financialization is stated as "taking more parts of financial markets, financial actors, financial motives and financial institutions in the functioning of local and international economies" according to Epstein's commonly accepted definition (Ayturk, 2011, p. 61). Actually, the rise of financialization came in question in the early 1980s, with in the process occurred after Keynesian paradigm ended (Arnum, 2011, p. 24). The increase of accessibility to loans in financial markets and forming a new work circuit by new politicians which is defined as Neo-Liberal box; has become effective in this issue. This work circuit is based on excessive financial expansion and low-priced importation, provides assurance to consumers and firms for expenses financed by loans. The rehabilitative effects of cheap importation on wage recession, expanding income inequality, labor loss in manufacture and increasing job insecurity is in the question (Palley, 2007, pp. 24-25).

It is brought forward that the financialization in other words the transfer of capitalism's centre from production to finance is a process which gives temporary vitality to system against economic recession on the other hand causing highly critical risks (Foster, 2011, p. 17). The growth ratios of wealthy countries in the center of capitalist world system have been ranging in low levels. In the circumstances of real economic recession, flow of extra money into finance sector has created an enormous financial structure on weakening economic foundations and application of speculative finance for creating prosperity led giant capital interests. Financialization can be observed by the indicators as increase of financial profit ratios, increase of the ration of debt/production, increase of share of finance, insurance and real estate in national dividend, increase of number of financial instruments and increase of financial bubbles (Kozanoglu, 2011, p. 18). An alternative view is that financialization symbolizes coming into prominence of accumulation brick provided by profits acquired from financial channels compared to production of commodities and trade (Krippner, 2005, p. 181).

It is also claimed that financialization is a strategy for eliminating the negative results of the low wages and weak investment propensity created by Neo-Liberalism. It can be accepted that comparative vitality of global economy could be a result of financialization depending upon prosperity effect and accessibility to loans. The transfer of center of capitalism to finance brought dominance of "shareholder value" which is one of the key concepts of the 
era. In accordance with this; the main mission of the company executive should be profit maximizing as per the demands of shareholders without giving consequence to social responsibility, public interest, employment (Kozanoglu, 2011, p. 55). This situation causes distribution of profit gained from production process to financial characteristic fields instead of new enterprises and undercuts the real economy (Levy-Orlik, 2013, p. 252). Hence, it has been occurred that corporate faces the exchange of profitability with growth of the firm which is propounded by the stylized facts agreed on by management history (Chandler), Post-Keynesian (Galbraith, Eichner) and contemporary management literature. It has become an issue of preferring profitability over corporate growth by getting close of management policies to shareholder preferences under the circumstances created by the differentiations in of performance-based salary system, threat of job loss which has arisen from the revolution of shareholder happened under control of the companies, in corporate structure (Stockhammer, 2004, p. 738).

\section{Summary of Literature}

It is encountered arguments relevant to that financialization causes negative effects on real and financial fields of an economy. These effects can be defined as moderate real economic growth, decreasing growth tendency, increasing income inequality, increasing share of financial asset owner in production. The effect of financialization on unemployment is also negative due to financial crises or decreasing capital accumulation. In addition to this, becoming common of automation in financial transactions contributes the decrease process of employment in a financialized economy (Assa, 2012, p. 35).

Stockhammer (2004, p. 739) achieved findings showing that financialization has a deceleration effect on capital accumulation. Despite these findings are supported strongly for USA and France, they are supported partially for United Kingdom, it is not supported at all for Germany. The curious point of it is that despite occurring of financialization in United Kingdom, the situation of not having a general deceleration of capital accumulation is grounded on the low-ranging ratio of capital accumulation since Golden Age in the country. On the other hand, Krippner (2005, p. 199) points out that the concept of financialization is a different phase of capitalism based on USA economy, mentions that the performed inquisitions are convenient for making inferences directed only to economic developments of post war era in the context of data existence and emphasizes that it is not possible to make determinations covering prewar eras in financial field. In that context, it is pointed out that financialization is a repetitive phase in the development process of capitalist economies.

Orhangazi (2007, p. 30) who approaches financialization in the terms of companies and capital market; indicates two aspects of financialization. First of these aspects is directing of excess amount of income in nonfinancial companies to financial sources by increasing their financials featured investments. The other aspect is causing an increasing pressure of financial markets on nonfinancial companies to transferring their earnings in financial market by buying profit share, repurchase of stocks additionally payment of interests. Dore (2008, p. 1110) emphasizes that as a simple function of financialization labor division; it causes expanding of financial sector nonproportionally in some countries and therewithal it is a parallel process to expansion of service sector. Accompanying of entertainment sector to expansion of financial services makes lots of financial asset owner and a simple logic explains the situation: Most of the speculators do not stake their own money.

Freeman (2010, p. 179) draws attention to that it can be taken three lessons from Wall Street model. First of all; it should be understood that financial markets can really succeed to destroy economies which cannot be made by labor markets. Secondly; the basic reasons of destroying financial markets are high level incentives in financial market in concurrence with taking excessive risks, cheating and financial fraud. The final lesson is that; the ability of being successful of reforms in financial field brings forth the need of a tough struggle necessitating compensative force covering the groups out of the sector. Arnum (2011, p. 24) points out that there are various channels of financialization towards to increasing income inequality. For as much as the process of financialization attracts the attention of rentiers of which's income raised by the increase of interest rate especially in 1980s and sets ground for growth of large financial companies. Indeed; Duenhaupt (2011) asserted that the differentiation resulted from financialization is in favor of rentiers for USA and Germany even it happened in different time periods. Despite that; Kedrosky and Stangler (2011, p. 14) emphasizes that financialization has a role in becoming prevalent and stronger of entrepreneurship in economy with the effect of the decreased constant cost occurred by technological developments.

Tang and Xiong (2012, p. 72) has reached the conclusion shows that financialization causes prices in commodity markets to become more relevant with each other gradually. Accordingly, it is seen that the price of a single commodity of financialization is determined by such factors as not only supply and demand of the product but also investment actions which vary according to risk appetite of total financial assets and commodity index. On 
the other hand, Kus (2012, p. 492) determined that financialization indicators and income inequality has a positive relation.

Tellalbasi and Kaya (2013, p. 136) have ascertained that the transformation of Turkish economy in direction of financialization has affected the capital accumulation process negatively depending on the reduction of investment trends. Correa et al. (2013, p. 272) have predicted about future of financialization process boldly. In accordance, study claims that the process of financialization is difficult to manage, expecting large financial crises prevents private sector firms from profitability possibilities in long-term and has the potential of creating difficulties on development of especially environmental economies with reference to Mexico example.

Levy-Orlik (2013, p. 253) states that financialization which Mexico has faced via globalization and process of adaptation to American economy results in continuation of chronic foreign trade deficit. The process of financialization causes dissolve of profits and liquid assets for profit motive in manufacturing directed sectors. Correa et al. (2013, p. 272) emphasize that it is not possible to predict the future of financialization however it is hard to create a sustainable accumulation regime in political manner.

\section{Aim, Method and Findings}

In this study; it has used panel data analysis in order to state the effects of financialization on employment and GDP depending on the data of G8 countries (USA, Germany, France, United Kingdom, Italy, Japan, Canada and Russia) for a period of 1990-2008. In determination of time period; the presence of acquired data from OECD (Organization for Economic Co-Operation and Development) and ILO (International Labor Office) database in entire countries has been effective as a limitation.

There are generally accepted advantages of panel data analysis for comparative data analysis depending on the increasing observation number (Plumper et al., 2005, p. 329). In spite of that, the various statistical difficulties which could be encountered in panel data analysis can be overcome with the models where panel standard errors and lagged value of dependent variable are used as explanatory variable (Beck \& Katz, 1995, p. 638).

In this study; this method has been used where it has been considered necessary. The model specified below is appropriate for the analysis of the effects of financialization on employment, gross domestic product and per capita income, and the financialization literature suggest that there have been significant relationships between the variables.

In this context, it has been used total employment, gross domestic product and per capita income as dependent variables. The main variables come from literature and also it has been used hours worked in an economy as a new aggregate variable and indicators below which represent various scales of financialization process as explanatory variables:

- $\quad$ Stock market capitalization ratio,

- Bank profitability stated as income before tax,

- Securities which are in bank assets,

- Value added in finance.

The aggregated form of variables referenced $\left(\mathrm{X}_{\mathrm{it}}\right)$ besides indicators representing financialization in models where all variables are taken in logarithmic forms; could be explained using the basic models below. The basic model templates given show that it has been used financialization indicators and relevant other macroeconomic indicators in order to explain the three different dependent variables for determining the relations explained in details with the findings. The details about explanatory variables which are shown as closed here have taken their places in following pages of the study. The basic model models which are the summary of models used in the analysis are as below:

$$
\begin{gathered}
G_{i t}=\alpha+\beta_{1} \text { FINANCIALIZATION }_{i t}+\beta_{2} X_{i t}+u_{i t} \\
G_{i t}=\alpha+\beta_{1} \text { GDP }_{i, t-1}+\beta_{2} \text { FINANCIALIZATION }_{i t}+\beta_{3} X_{i t}+u_{i t} \\
\text { EMP }_{i t}=\alpha+\beta_{1} \text { FINANCIALIZATION }_{i t}+\beta_{2} X_{i t}+u_{i t} \\
\text { GNI_PC }_{i t}=\alpha+\beta_{1} \text { FINANCIALIZATION }_{i t}+\beta_{2} X_{i t}+u_{i t}
\end{gathered}
$$

The model of which basic forms are given above; are formed in the axis of financialization and gross domestic product, financialization and total employment, financialization and per capita income. In order to present the assumption results of explanatory variables in different situations and to be able to compare the finding; a wide range of models have been estimated. 
All variables used in the estimated models and their explanations are as below:

- Gross domestic product (GDP),

- Employment in total (EMP),

- Per capita income (GNI_PC),

- Hours worked in economy (HW),

- Value added created in finance (VA_F),

- $\quad$ Stock market capitalization rate (SMC),

- $\quad$ Securities which are in bank assets, (SEC),

- Bank profitability stated as income before tax (IBT).

The analysis results of fixed effects model in which the effect of financialization on gross domestic product is analyzed are given in Table 1. It has been seen that stock market capitalization rate and bank securities which are two of variables representing financialization process have a positive effect on gross domestic product in parallel to literature. By contrast with this; the variable of bank profitability has received negative coefficient in all models. Another result acquired from models is that hours worked in economy and value added in finance has a positive effect on gross domestic product.

Table 1. Financialization and GDP: panel data analysis (1990-2008)

\begin{tabular}{llllll}
\hline & Model 1 & Model 2 & Model 3 & Model 4 & Model 5 \\
\hline IBT & $-0.006^{* *}$ & $-0.001^{* * *}$ & & $-0.005^{* * *}$ & \\
& $(0.002)$ & $(0.001)$ & & $(0.001)$ & \\
SEC & $0.120^{* *}$ & & $0.126^{* * *}$ & $0.128^{* * *}$ \\
& $(0.048)$ & & $(0.027)$ & $(0.028)$ \\
SMC & $0.215^{* * *}$ & & $0.102^{* * *}$ & $0.097^{* * *}$ \\
& $(0.041)$ & & $0.030^{*}$ & $(0.015)$ & $(0.020)$ \\
HW & & & $(0.014)$ & $1.693^{* * *}$ & $1.726^{* * *}$ \\
& & & & $(0.298)$ & $(0.342)$ \\
VA_F & & & & & \\
& & $0.722^{* * *}$ & $0.660^{* * *}$ & & \\
CONS & $3.288^{* * *}$ & $-15.080^{* * *}$ & $-13.869^{* * *}$ & $-4.013^{* * *}$ & $-4.192^{* *}$ \\
& $(0.275)$ & $(1.443)$ & $(1.436)$ & $(1.359)$ & $(1.537)$ \\
N & 117 & 118 & 131 & 117 & 117 \\
\hline
\end{tabular}

Source: Authors' own calculations.

Note. It is given the robust standard errors in parenthesis. ${ }^{*} \mathrm{p}<0.10,{ }^{*} \mathrm{p}<0.05,{ }^{* * *} \mathrm{p}<0.01$.

As explained previously in the study, some methodological obligations in panel data analysis have necessitated the use of Generalized Method of Moments (GMM) in order to acquire better results in the analysis. Especially in circumstances where explanatory variables are not strictly exogenous; GMM estimators are appropriate for panel data analysis (Roodman, 2006, p. 1).

It is given the dynamic panel data models acquired from GMM estimators (Arellano-Bond) in Table 2 (Arellano $\&$ Bond, 1991). The results of the analysis show that the findings gained from GMM estimators are consistent with other findings. In the GMM models where it is analyzed the effects of financialization on gross domestic product, it is seen that stock market capitalization rate, securities and bank profitability; some of the financialization process representing variables; have positive effect on gross domestic product. 
Table 2. Financialization and GDP: GMM analysis (1990-2008)

\begin{tabular}{llllll}
\hline & Model 1 & Model 2 & Model 3 & Model 4 & Model 5 \\
\hline GDP $_{\mathrm{t}-1}$ & $0.590^{* * *}$ & $0.691^{* * *}$ & $0.696^{* * *}$ & $0.674^{* * *}$ & $0.706^{* * *}$ \\
& $(0.100)$ & $(0.108)$ & $(0.131)$ & $(0.137)$ & $(0.105)$ \\
IBT & $0.001^{* * *}$ & $0.001^{* * *}$ & $0.001^{* * *}$ & & $0.001^{* * *}$ \\
& $(0.001)$ & $(0.001)$ & $(0.001)$ & & $(0.001)$ \\
SEC & $0.031^{* * *}$ & $0.027^{* * *}$ & $0.028^{* * *}$ & $0.031^{* * *}$ & \\
& $(0.006)$ & $(0.007)$ & $(0.008)$ & $(0.011)$ & \\
SMC & $0.011^{*}$ & $0.011^{*}$ & & & $0.014^{* *}$ \\
& $(0.006)$ & $(0.006)$ & & & $(0.006)$ \\
HW & $0.148^{*}$ & & & & \\
& $(0.077)$ & & & & \\
VA_F & $0.241^{* * *}$ & $0.202^{* *}$ & $0.213^{* *}$ & $0.222^{* *}$ & $0.196^{* *}$ \\
& $(0.064)$ & $(0.080)$ & $(0.105)$ & $(0.113)$ & $(0.086)$ \\
CONS & $-5.489^{* * *}$ & $-4.210^{* *}$ & $-4.490^{* *}$ & $-4.632^{*}$ & $-4.043^{* *}$ \\
& $(1.428)$ & $(1.700)$ & $(2.270)$ & $(2.469)$ & $(1.870)$ \\
$\mathrm{N}$ & 105 & 105 & 106 & 106 & 105 \\
\hline
\end{tabular}

Source: Authors' own calculations.

Note. It is given the robust standard errors in parenthesis. $* \mathrm{p}<0.10, * * \mathrm{p}<0.05, * * * \mathrm{p}<0.01$

The analysis results of fixed effects model in which the effect of financialization on total employment is analyzed are given in Table 3. It has been seen that stock market capitalization rate and bank securities which are two of variables representing financialization process have a positive effect on total employment. By contrast with this; the variable of bank profitability has received negative coefficient in all models. Another result acquired from models is that hours worked in economy and value added in finance has a positive effect on total employment. It has been seen that the differentiation in the management aspects of the companies arisen from financialization basing on the increase in shareholder value results in the focusing of management on making profit in force, increase of employing managers with wage dividend depending on profitability (Arestis et al., 2013, p. 171) and due to this making arrangement in order to reduce labor costs thus it is seen increase of employment in general (Batt \& Eileen, 2013, p. 36). This development resulted in breaking the links between wage, efficiency and profitability which have been subjected to further discussions in the aspects of financialization (Rossman \& Greenfield, 2006, p. 9).

Table 3. Financialization and total employment: Panel data analysis (1990-2008)

\begin{tabular}{llllll}
\hline & Model 1 & Model 2 & Model 3 & Model 4 & Model 5 \\
\hline IBT & $-0.001^{* * *}$ & & $-0.002 * *$ & & $-0.001 * * *$ \\
& $(0.001)$ & & $(0.001)$ & & $(0.001)$ \\
SEC & $0.029 *$ & & $0.030^{*}$ & \\
& $(0.012)$ & & & $(0.013)$ & \\
SMC & $0.033^{* *}$ & & $0.099 * *$ & $0.031^{* *}$ & $0.038^{*}$ \\
& $(0.010)$ & & $(0.030)$ & $(0.010)$ & $(0.018)$ \\
HW & $0.941^{* * *}$ & & & $0.951^{* * *}$ & $0.938^{* * *}$ \\
& $(0.095)$ & & & $(0.098)$ & $(0.103)$ \\
VA_F & & $0.263^{* * *}$ & & & \\
& & $(0.058)$ & & & $5.991 * * *$ \\
CONS & $5.915^{* * *}$ & $3.248^{*}$ & $10.031^{* * *}$ & $5.863 * * *$ & $(0.414)$ \\
& $(0.382)$ & $(1.594)$ & $(0.123)$ & $(0.390)$ & 117 \\
\hline
\end{tabular}

Source: Authors' own calculations.

Note. It is given the robust standard errors in parenthesis. ${ }^{*} \mathrm{p}<0.10, * * \mathrm{p}<0.05, * * * \mathrm{p}<0.01$.

The analysis results of fixed effects model in which the effect of financialization on per capita income is analyzed are given in Table 4 . It has been seen that stock market capitalization rate and bank securities which 
are two of variables representing financialization process have a positive effect on per capita income. By contrast with this; the variable of bank profitability has received negative coefficient in all models. Another result acquired from models is that value added in finance has a positive effect on per capita income.

Table 4. Financialization and per capita GDP: Panel data analysis (1990-2008)

\begin{tabular}{llllll}
\hline & Model 1 & Model 2 & Model 3 & Model 4 & Model 5 \\
\hline IBT & $-0.013^{* * *}$ & $-0.002^{* *}$ & $-0.013^{* * *}$ & & \\
& $(0.002)$ & $(0.001)$ & $(0.002)$ & & \\
SEC & $0.151^{* *}$ & & & & \\
& $(0.060)$ & & & & \\
SMC & $0.385^{* * *}$ & $0.081^{* *}$ & $0.412^{* * *}$ & $0.067^{* *}$ & \\
& $(0.041)$ & $(0.026)$ & $(0.061)$ & $(0.027)$ & \\
VA_F & & $1.063^{* * *}$ & & $1.108^{* * *}$ & $1.200^{* * *}$ \\
& & $(0.045)$ & & $(0.057)$ & $(0.069)$ \\
CONS & $8.257^{* * *}$ & $-18.888^{* * *}$ & $8.587^{* * *}$ & $-20.727^{* * *}$ & $-22.968^{* * *}$ \\
& $(0.283)$ & $(1.154)$ & $(0.248)$ & $(1.540)$ & $(1.911)$ \\
$\mathrm{N}$ & 117 & 117 & 117 & 131 & 132 \\
\hline
\end{tabular}

Source: Authors' own calculations.

Note. It is given the robust standard errors in parenthesis. ${ }^{*} \mathrm{p}<0.10,{ }^{* *} \mathrm{p}<0.05,{ }^{* * *} \mathrm{p}<0.01$.

\section{Conclusion}

In the recent history of world economy; a period has prevailed when finance sector has gained the majority in economic structure. In this period; finance markets have been perceived as mechanism which would provide economic efficiency and growth within the scope of accepted economic concept. Financialization has appeared as a concept which defines increasing significance of financial markets, financial motives, financial institutions and financial exclusives which take part in process of economy in national and international the levels in the era occurred after Keynesian paradigm ended in 1970s.

The transfer of capitalism's centre from production to finance via financialization gives temporary vitality to system against economic recession on the other hand causes highly critical risks. In the circumstances of economic recession, flow of extra money into finance sector has created an enormous financial superstructure on weakening economic foundations and brought the question of giant capital interests which has not any direct links to commodity economy.

Information relating that financialization affects on real and financial sections of economy negatively is encountered in literature. These effects can be defined as moderate real economic growth, decreasing growth tendency, increasing income inequality, increasing share of financial asset owner in production and GDP. The effect of financialization on unemployment is also negative due to financial crises or decreasing capital accumulation.

In the paper; it has been examined the effects of financialization on employment and production in economy using the data for G8 countries in the period of 1990-2008 to explore the effects of financialization on the developed countries. The performed econometric analysis has shown that financialization has a major effect on economy towards production and employment in the scope of value added in finance and financialization indicators in G8 countries. Also all indicators of financialization that employed in analysis have displayed a robust relation.

The results show that financialization and some macroeconomic indicators on sectoral basis generate an increasing effect on gross domestic product in general. It has also concluded that all explanatory variables except bank profitability from all variables used in the study affect total employment and per capita income in economy positively. Based on these results conclude that financialization has caused an upward contribution on overall economic conditions.

The empirical results summarized above have also important policy implications which contribute to the debates about the effects of financialization. Thus, it is possible to take advantages of financialization process for the developed countries. Therefore, it can be said that developed countries must focus on financialization process to improve their economic conditions. Definitely, it is necessary to investigate the different aspects of this issue. 
Because it is possible to investigate the other aspects of financialization that this paper does not cover.

\section{Acknowledge}

This article is the updated version of the paper presented in the $1^{\text {st }}$ EY International Congress on Economics in May $24^{\text {th }} \& 25^{\text {th }} 2013$ in Ankara/Turkey organized by Gazi University.

\section{References}

Arellano, M., \& Bond, S. (1991). Some tests of specification for panel data: Monte Carlo evidence and an application to employment equations. Review of Economic Studies, 58, 277-297. http://dx.doi.org/10.2307/2297968

Arestis, P., Charles, A., \& Fontana, G. (2013). Financialization, the great recession, and the stratification of the US labor market. Feminist Economics, 19, 152-180. http://dx.doi.org/10.1080/13545701.2013.795654

Arnum, B. (2011). Income Inequality and Financialization in the United States. New Jersey: The College of New Jersey.

Assa, J. (2012). Financialization and its consequences: the OECD experience. Finance Research, 1, 35-39.

Aydin, M. K. (2007). Türkiye ekonomisinin dönüşümü: 'ithal ikamecilik'ten 'dışa açık' birikim modeline savruluş. In D. Dursun, B. Duran \& H. Al (Eds.), Dönüşüm Sürecindeki Türkiye: Aktörler, Alanlar, Sorunlar (pp. 303-24). Istanbul: Alfa.

Ayturk, Y. (2011). Finansallasma ve reel ekonomi. In H. Kozanoglu (Ed.), Uç(ur)amayan Balon: Finans (pp. 60 90). Istanbul: Ayrintı.

Batt, R. L., \& Eileen, A. (2013). The impact of financialization on management and employment outcomes. W.E. Upjohn Institute for Employment Research, Upjohn Institute Working Paper No: 13-191, Kalamazoo.

Beck, N., \& Katz, J. N. (1995). What to do (and not to do) with time-series cross-section data. The American Political Science Review, 89, 634-647. http://dx.doi.org/10.2307/2082979

Camacho, C. M., \& Nieto, J. A. R. (2009). Finansal sermayenin küreselleşmesi: 1997-2008. In C. Lapavitsas (Ed.), Finansallaşma ve Kapitalizmin Krizi (pp. 225-255). Istanbul: Yordam.

Correa, E., Vidal, G., \& Marshall, W. (2013). Financialization in Mexico: trajectory and limits. Journal of Post Keynesian Economics, 35, 255-275. http://dx.doi.org/10.1080/13545701.2013.795654

Dore, R. (2008). Financialization of the global economy. Industrial and Corporate Change, 17, $1097-1112$. http://dx.doi.org/10.1093/icc/dtn041

Duenhaupt, P. (2011). Financialization and the rentier income share-evidence from the USA and Germany. International Review of Applied Economics, 26, 465-487. http://dx.doi.org/10.1080/02692171.2011.595705

Ercan, M. (2012, March). Finansal küreselleşme, yapısal değişim ve büyüme. Radikal Gazetesi. Retrieved from http://www.radikal.com.tr

Foster, J. B. (2011). Tekelci finans sermaye çağı. In H. Tanıttıran (Ed.), Tekelci Finans Sermayesi (pp. 11-26). Istanbul: Kalkedon.

Freeman, R. B. (2010). It's financialization! International Labour Review, 149, $163-183$. http://dx.doi.org/10.1111/j.1564-913X.2010.00082.x

Hirst, P., \& Thompson, G. (2007). Küreselleşme Sorgulanıyor. Ankara: Dost.

Kaufman, G. G. (1973). Money, the Financial System, and the Economy. Chicago: Rand McNally.

Kedrosky, P., \& Stangler, D. (2011). Financialization and Its Entrepreneurial Consequences. Kauffman Foundation Research Series: Firm Formation and Economic Growth, Ewing Marion Kauffman.

Kidwell, D. S., \& Peterson, R. L. (1990). Financial Institutions, Markets, and Money. Orlando: the Dryden.

Kozanoglu, H. (2011). Finansallaşma ve Türkiye. In H. Kozanoglu (Ed.), Uç(ur)amayan Balon: Finans (pp. 1159). Istanbul: Ayrint1.

Krippner, G. R. (2005). The financialization of the American economy. Socio-Economic Review, 3, $173-208$. http://dx.doi.org/10.1093/SER/mwi008

Kumar, K. (2010). Sanayi Sonrası Toplumdan Post-Modern Topluma: Çağdaş Dünyanın Yeni Kuramları. Ankara: Dost.

Kus, B. (2012). Financialisation and income inequality in OECD nations: 1995-2007. The Economic and Social 
Review, 43, 477-495.

Lapavitsas, C. (2009). Finansallaşmış kapitalizm: kriz ve finansal müsadere. In C. Lapavitsas (Ed.), Finansallaşma ve Kapitalizmin Krizi (pp. 25-74). Istanbul: Yordam.

Levy-Orlik, N. (2013). Effects of financialization on the structure of production and nonfinancial private enterprises: the case of Mexico. Journal of Post Keynesian Economics, 35, $235-254$. http://dx.doi.org/10.2753/PKE0160-3477350204

Orhangazi, O. (2007). Financialization and capital accumulation in the non-financial corporate sector: a theoretical and empirical investigation of the U.S. economy: 1973-2003. University of Massachusetts Amherst Working Paper Series No. 149. Amherst: Political Economy Research Institute.

Palley, T. I. (2007). Financialization: what it is and why it matters. The Levy Economics Institute, Working Papers No. 525.

Plumper, T., Troeger, V. E., \& Manow, P. (2005). Panel data analysis in comparative politics: linking method to theory. European Journal of Political Research, 44, 327-354. http://dx.doi.org/10.1111/j.1475-6765.2005.00230.x

Roodman, D. (2006). How to do xtabond2: an introduction to "difference" and "system" GMM in Stata. Center for Global Development, Working Paper No. 103.

Rossman, P., \& Greenfield, G. (2006). Financialization: New routes to profit, new challenges for trade unions. Labour Education, 142, 1-10.

Sen, A. (2005). Washington konsensüs ve gelişmekte olan ülkeler sorunları: eleştirel bir değerlendirme. Süleyman Demirel Üniversitesi İktisadi ve İdari Bilimler Fakültesi Dergisi, 10, 181-200.

Standing, G. (2010). Work after Globalization: Building Occupational Citizenship. Cheltenham: Edward Elgar.

Stockhammer, E. (2004). Financialization and the slowdown of accumulation. Cambridge Journal of Economics, 28, 719-741. http://dx.doi.org/10.1093/cje/beh032

Tang, K., \& Xiong, W. (2012). Index investment and the financialization of commodities. Financial Analysts Journal, 68, 54-74. http://dx.doi.org/10.2469/faj.v68.n6.5

Tellalbasi, I., \& Kara, F. (2013). Financialization of Turkey industry sector. International Journal of Financial Research, 4, 127-143. http://dx.doi.org/10.5430/ijfr.v4n3p127

United Nations. (2008). Küresel eşitsizlik biçimleri. In D. Held \& A. McGrew (Eds.), Küresel Dönüşümler: Büyük Küreselleşme Tartışması (pp. 502-509). Ankara: Phoenix.

\section{Copyrights}

Copyright for this article is retained by the author(s), with first publication rights granted to the journal.

This is an open-access article distributed under the terms and conditions of the Creative Commons Attribution license (http://creativecommons.org/licenses/by/3.0/). 